\title{
Study on the Reconstruction of Shanxi Local Tax System after the Full Implementation of Reform by Business Policy
}

\author{
Min Guo \\ Xi'an International University, 710077, Xi'an Shaanxi, China
}

Keywords: "reform by business"; local tax system; reconstruction study

\begin{abstract}
Reform by Business" is an important macro-adjustment tactic in China. It also marks the beginning of new era in China's tax reform. With the full implementation of the "reform by business", the traditional local taxation system industry will certainly be affected. As the "reform by business" on the local economy and the tax system have had a huge impact, so to re-build a new local tax system has become an important part of the local government financial sector work. This paper will take Shanxi as an example to elaborate the reconstruction of the local tax system after the full implementation of the reform.
\end{abstract}

\section{Introduction}

"Reform by business" can be said to a large extent changed our tax system, China will introduce a new stage of taxation. And the traditional tax system established by the local tax system is bound to be broken, facing the situation of reconstruction. After the full implementation of the reform, the economic development of Shanxi Province has been greatly improved and the financial income of Shanxi has been increased. If we continue to use the traditional tax system, not only can not reflect the "reform by business" the advanced nature and effect, but also for serious constraints to the sustainable development of the local economy. Therefore, it is very important and effective to study and look at the reconstruction of local taxation system in Shaanxi Province from the angle of comprehensive implementation.

\section{The Economic Influence of "Reform by business" on Shanxi Province}

Before the full implementation of the reform, the proportion of the tertiary industry in Shaanxi was only $34.8 \%$, which was lower than the average level of $40 \%$ in our country. In the "reform by business" after the full implementation of the proportion of Shaanxi's tertiary industry has been rapid growth. Among them, science and technology innovation, cultural industry and service industry development is the most rapid. In the "reform by business" policy, the full implementation of science and technology innovation industry tax rate rose to $6 \%$. Although in the long run, the industry as a whole is to reduce the tax revenue, but to promote its development. The cultural industry tax rate has also been reduced; more effectively promote the healthy development of local cultural industries. The "reform by business" is to promote the refinement of the service industry, to achieve a "double taxation", but also to promote the stability of the local logistics industry development.

Although the overall point of view, Shanxi local tax revenue will show a downward trend, the local fiscal revenue must also be affected. But it can effectively promote the development of local industries, especially the tertiary industry. When the competitiveness of enterprises and investment have been enhanced, corporate profits will be correspondingly enhanced, then the value-added tax will increase. From a long-term point of view, "business change" can promote the competitiveness and development of enterprises, by increasing the turnover of enterprises to increase revenue.

The traditional tax system countries in the "business change" implemented before the tax system developing. In the full implementation of the "business change", will increase the difficulty of Shaanxi Province, the tax collection and management, and for the work of the land tax system will have a great impact. The implementation of "reform by business" increased national taxes, breaking 
the traditional state tax and land tax self-contained situation [1]. How to coordinate the relationship between the tax and deal with the issue of convergence and collection is the traditional tax collection needs to face the first question. After the implementation of the "reform by business", it should be changed from the business tax with the land tax to the value-added tax managed by the national tax, which will change the collection and management functions of the local tax. From the relevant data, the Shanxi local tax will be 33.284 billion Yuan, which will be handed over to the state tax system collection and management, and how to handle the work of the middle docking and handle the relevant information, are very cumbersome and important work [2].

\section{The Influence of "Business Reform" on Shaanxi Local Tax System}

In China, the local government for local taxes has no control and decision-making power, the lack of adequate autonomy of the tax. Although many local public services are provided by the local government, local governments can not use or control tax revenues. After the full implementation of the "business transformation," the business tax, which should have been managed by the local government, has become a category of value-added tax managed by the state, which will further increase the financial pressure of the local government [3]. This is likely to lead to the phenomenon of local arbitrary charges, and increase the local government for land finance. If we cannot solve these problems fundamentally and deal with the relationship between local and national tax rights, will affect the local land trading market in Shanxi, thus affecting the region's overall economic development.

As mentioned above, after the full implementation of the "business reform", the local government's revenue will continue to decline. Shanxi Province needs to hand 33.284 billion Yuan of business tax transferred to the country, which is to reduce the Shanxi finance a huge and important income. Business tax as an important basis for maintaining the daily management of local governments, the reduction of tax revenue will inevitably affect the management of the entire government work and conduct. Although in the long run, "business reform" is conducive to promote local economic development, so that local fiscal revenue achieving increases. But how to handle the current due to lower tax revenue arising from a series of questions, Shanxi government and relevant departments need to be resolved.

Before the full implementation of the "business reform", the local and central tax authorities had a clear division of responsibilities, local governments only need to complete the transfer payment work to the central government, and local revenues do not need to be turned over to the central government. Thus the land tax and state tax separated. When the "tax reform" fully implemented, most of the business taxes are transferred to the state tax. The tax needs to re-integrate the taxpayer's data and filing, and this part of the information required to provide most of the land tax. At the same time the local land tax situation is different, need to integrate the material also has differences [4]. How to successfully complete the handover of these data, increase the local tax and the tax with the degree of land tax management is an important part of the work. At the same time as the local collection and management business to reduce the number of positions need to remove or changing of the guard. How to establish an effective local tax collection management system, re-positioning the contents and responsibilities of various posts to ensure the efficiency of local tax management, local governments and relevant departments need to deal with the focus of the work.

\section{Suggestions on the Reconstruction of Local Tax System in Shaanxi Province}

The current Shanxi government does not have sufficient tax legislation power, which has some extent limit the local government to establish a tax system in line with local taxation. As the natural conditions of each place, there are differences in economic conditions, the central government should give the local government appropriate tax legislation. The central government can let local governments have the necessary tax rates to regulate local taxes. Shanxi local government in accordance with the local economic situation, fully and reasonable use of their legislative power to ensure that the local tax system is conducive to promoting local economic development, and does 
not run counter to national development strategy.

Shanxi business tax is gradually shrinking; no tax can bring a fixed income. Although there are still a variety of local, fragmented small tax, but not yet complete the scale of the formation of the tax system. Shanxi region can be combined with the local economic structure and development, learn from foreign experience, scientific establishment of the main tax taxes, such as the establishment of property taxes. Since 2001, per capita disposable income of urban households in Shanxi has been greatly improved, and incomes and disposable assets have also been improved. This has provided an important tax source guarantee for the taxation of the province. As an important province in the northwest of China, Shanxi has a large population and a relatively rigid demand, thus promoting the rapid development of the local real estate industry [5]. In recent years, the real estate investment on the open rate of steady development of the situation, the value of real estate will continue to be improved. All of these provide a stable and strong source of taxes for property taxes. The establishment of property tax is also an important way to maintain social equity and achieve common prosperity. Taxation of certain stock assets is an important lever for regulating the gap between the rich and the poor. It is also conducive to the establishment of an indirect tax system with commodity turnover tax as the main body. In the light of the local real estate situation in Shanxi, I think that the Shanxi government can establish the property tax from the following aspects: (1) the collection of real estate tax: to Shanghai, Chongqing, the first batch of " Secondly, to have more than two sets (not including two sets) of real estate tax; the last part of the housing area beyond the provisions of the country on the part of the real estate tax levied on the first commercial housing; tax. (2) Improve the land value - added tax: land value - added tax is conducive to enhancing the state's openness to the land and the real estate market macro - control capacity. Shanxi government according to the actual situation of the local economic adjustment of land value-added tax, and improve the land value-added tax calculation and collection methods. (3) Improve the urban land use tax: Shanxi local use of land-use water standards are still before. With the continuous development of the local economy, the traditional urban land use tax is not only lower than the market price, but also to a certain extent, limits the development and utilization of urban land. The Shanxi government should introduce the urban land tax into the local land market price mechanism to ensure the value and utilization rate of the land.

As mentioned above, "business reform" after the full implementation, increased the cooperation between the national tax and land tax and collaboration. Only from the collection of value-added tax collection point of view, the tax department has more advantages. But the land tax department should also deepen the "camp to change" the impact and related industries involved in the understanding, re-develop effective management system and system. Shanxi local tax should uphold the "people with the business to go" principle, according to the land tax business to re-allocate the development of different job content, responsibilities and systems, will be responsible for the former business tax collection and management departments and personnel into the current tax department, Institutional integration [7]. At the same time to establish the relevant supporting measures to develop effective accountability and expenditure responsibility management system. Reduce the "tax reform" the initial implementation of the contradictions at the same time, to maximize the local tax collection and management departments.

\section{Conclusion}

Although the "business change" to China's tax administration system into another stage, but it also on the Shanxi local tax system caused no small impact. In the process of rebuilding the new tax system, the central government should give Shaanxi local government appropriate tax legislative power, establish and improve the tax law, establish the scientific tax main tax, and pay attention to improve the local tax collection and management efficiency. To lay a good foundation for the reconstruction of Shaanxi local tax system, to achieve the implementation of "battalion change" the full implementation of the same time, to ensure that local revenue. 


\section{References}

[1] Path Choice of Local Tax System Construction under the Background of "Business Reform" [J]. Journal of Harbin University of Commerce (Social Science Edition), Xiaoqin Han, Yongxu Cao. 90-98, 2016, 01

[2] Discussion on the influence of comprehensive "business reform" on local finance and taxation [J]. Zhijiang Song, Zhengqiang Liu, Rong Liu. Audit \& Finance, 26-29. 2016, 06

[3] Research on the Perfection of Local Tax System after "Business Reform" [J]. Lingli Qing, Jingxiao Qu, Chunhui Wen.Tax Economics Research, 28-32. 2016, 03.

[4] Hengyang City Local Taxation Bureau Task Force, Ceng Xiu, Yang Aiguo, Wang Qiong. "Localization of local tax revenue management system after restructuring" [J]. Journal of Hunan Tax College, 2016,03: 13- $15+26$.

[5] "Business Reform" after the reconstruction of China's local tax system of the basic ideas [J]. Bing Wang. Financial supervision, 21-24. 2016, 10

[6] "Battalion change" on the impact of economic development in Shaanxi [J]. Chao Wang, Quansheng Zhang. Shanxi Administration, 101-104. 2014, 03

[7] "Reform of tax," the local fiscal and taxation system of thinking [J]. Wenzhi Zhong, Registered CTA, 39-40. 2013, 12 